\title{
"NEW THINKING ABOUT AN OLD ISSUE:" THE ABORTION CONTROVERSY CONTINUES IN RUSSIA AND IRELAND - COULD ROE V. WADE HAVE BEEN THE BETTER SOLUTION?
}

\author{
Kelley J. Johnson*
}

\begin{abstract}
We forthwith acknowledge our awareness of the sensitive and emotional nature of the abortion controversy, of the vigorous opposing views, even among physicians, and of the deep and seemingly absolute convictions that the subject inspires. One's philosophy, one's experiences, one's exposure to the raw edges of human existence, one's religious training, one's attitudes toward life and family and their values, and the moral standards one establishes and seeks to observe, are all likely to influence and to color one's thinking and conclusions about abortion. $^{2}$
\end{abstract}

\section{INTRODUCTION}

Abortion is defined as "[t]he spontaneous or artificially induced expulsion of an embryo or fetus." ${ }^{3}$ However, human abortion has long been understood to mean "an intentionally-induced miscarriage" rather than a miscarriage "resulting naturally or by accident." In the United States, abortion has always been an emotive issue, and it continues to ignite passions in those who support and oppose the procedure. ${ }^{5}$ The same passions that arose in the United States after Roe v. Wade ${ }^{6}$ continue to rise in Ireland ${ }^{7}$ and Russia. ${ }^{8}$

* J.D. Candidate, 2005, Indiana University School of Law - Indianapolis (expected); Bachelor of Science, Purdue University, 1992. The author wishes to thank her husband, Chad, and her family for their continued patience, support and understanding throughout law school.

1. Roe v. Wade, 410 U.S. 113, 116 (1973) (quoting Justice Blackmun).

2. Id.

3. BLACK's LAW DictionaRY 6 (8th ed. 2004).

4. Id. at 6 (quoting Rollin M. PERKINS \& RONALd N. BoyCE, CrIminal LaW 186-87 (3d ed. 1982)).

"There has been some tendency to use the word to mean a criminal miscarriage,... but there are so many references to lawful abortion ... that it is necessary to speak of 'criminal abortion' or the "crime of abortion' to emphasize the element of culpability." Id.

5. See Donald P. Judges, HaRd Choices, LOST Voices: How the Abortion CONFICT has Divided America, Distorted CONSTITUtIONal Rights, and DaMaged the COURTS 4-5 (1993).

6. 410 U.S. 113.

7. See Kitty Holland, Twenty Years of Antenatal Politics, The 20th Anniversary of Ireland's First Abortion Referendum Looms, but the Issue Remains as Emotive as Ever, IRISH 
This Note will explore three countries, each with very different abortion laws: the United States, Ireland and Russia. The United States, where abortion became legal with guidelines following the fairly recent decision in 1973 of Roe v. Wade, ${ }^{9}$ will be compared to Ireland, where abortion has been illegal since 1861 with very few exceptions. ${ }^{10}$ In contrast to both the United States and Ireland, abortion in Russia has been legal with little restriction since 1920. ${ }^{11}$ Each country has a different solution to abortion. ${ }^{12}$ The pendulum swings from the lenient laws in Russia ${ }^{13}$ to the stringent laws in Ireland. ${ }^{14}$ Although the abortion laws in Ireland and Russia are opposite, both have led to devastating effects on pregnant women obtaining abortions. ${ }^{15}$ Could the judicial decision in Roe have been the better solution?

Part II of this Note will look at the United States; Part III will examine Ireland; and Part IV will examine Russia. Section A of each Part will focus on the history of abortion in each country, examining the changing views and practices of abortion and the implementation and modification of abortion legislation and case law. Section B will discuss the consequences that the legislation and case law had on the citizens and on the country itself. Section B will also study the effect that legalizing or restricting abortion has had on women seeking an abortion in each country. Section $C$ of each part will explore where the abortion controversy stands today, what laws are in effect at this time, and how each country is responding to those laws. Finally, Section D will look at where abortion laws might be headed in the future and why each country is headed in that direction.

In conclusion, Part $\mathrm{V}$ will contemplate the question: Is the United States' Roe v. Wade the better solution to abortion for Ireland and Russia? The analysis supplies the conclusion that although Roe $v$. Wade might be a middleground solution between the two extremes, the better answer for the future of Ireland and Russia is to focus on education and advances in technology of birth control. Regardless, as shown from the United States' history before Roe and the current situation in Ireland, a country cannot force acceptance of an unpopular law and should look for other solutions to remedy its problem.

TIMES, Sept. 3, 2003, at 13 [hereinafter 20th Anniversary].

8. See Associated Press, Russian Abortion Debate Grows, at http://www.forenunner.com/ predvestnik/X0059_Russias_abortion_pol.html (n.d.) (last visited Sept. 25, 2004) [hereinafter Russian Abortion Debate].

9. See infra Part II.A.

10. See infra Part III.A.

11. See infra Part IV.A.

12. See infra Parts II.A, III.A, IV.A.

13. See infra Part IV.A.

14. See infra Part III.A.

15. See infra Part III.B, IV.B. 


\section{ABORTION IN THE UNITED STATES}

\section{A. Historical Aspect}

During the 1700s, abortion was not uncommon in colonial America. ${ }^{16}$ Midwives routinely provided women with herbal abortifacients. ${ }^{17}$ There was an "absence of legal condemnation" of abortion even though families and society valued both children and population growth in times of vast unsettled lands and high infant mortality. ${ }^{18}$ If abortion was chastised at all, it was the violation of sexual norms, not the practice itself that was condemned. ${ }^{19}$ In the late 1700 s, the restrictive views on sexual behavior "loosened considerably." 20 Despite the relaxation of sexual standards, the drafters of the United States Constitution did not mention abortion within its four corners. ${ }^{21}$ There is no mention of abortion by name or by inference in the original articles, the Bill of Rights, or in any subsequent amendments. ${ }^{22}$

Through the nineteenth century, abortion remained widely accepted. ${ }^{23}$ Women used abortion as "conscious fertility control" because of economic pressures and the redefining role of motherhood. ${ }^{24}$ During this time, the most common methods of abortion involved the use of herbs and devices women purchased from local pharmacists; however, abortion practitioners soon became prevalent. $^{25}$ By 1840 , abortion developed into a business with some practitioners going so far as making abortion their "chief livelihood." Ironically, during the same time that practitioners began to benefit from performing abortions as a business, physicians also became the principal proponents of laws to restrict abortion. ${ }^{27}$

16. Eva Rubin, The Abortion Controversy: A Documentary History 11 (1994).

17. Id. "Abortifacients" are things that cause abortions. Id. Recipes for the herbal potions were found in cookbooks and diaries of women from that era. Id.

18. Id. For the aforementioned reasons, abortions were most common among single women in colonial times. Id. It is also unusual that abortion was not legally condemned in the tight-knit religious New England communities. Id.

19. Id.

20. Id. at 16. During the late 1700 s it was estimated that "one third of all New England brides were pregnant at the time of marriage, compared to less than $10 \%$ in the seventeenth century." Id.

21. See John T. Noonan, JR., A Private Choice: Abortion In America in the SEVENTIES 5 (1979).

22. Id.

23. RUBIN, supra note 16 , at 12 .

24. Id. "The good bourgeois wife was to limit her fertility, symbolize her husband's affluence, and do good within the world." Id.

25. Id. at 12-13.

26. Id. at 13.

27. RUBIN, supra note 16 , at 13-14. Between 1850 and 1880 , the newly formed American Medical Association became the "single most important factor in altering the legal policies toward abortion ...."Id. at 13. Physicians wanted to restrict abortion over concerns of maternal health, consumer protection, the discriminatory idea of the subordination of women, 
The first anti-abortion laws were "anti-poisoning" statutes rather than prohibitions on all abortions. ${ }^{28}$ Because the herbal abortifacients could be fatal to the woman if taken in excessive quantities, it became a crime to "administer" the poisons. ${ }^{29}$ These laws were drafted to protect women. As such, women who obtained an abortion were not punished if they received but did not administer the poisons. ${ }^{30}$ Even though these early anti-abortion laws were in effect, they were not enforced. ${ }^{31}$ Because abortion was still prevalent, the "openly tolerated practice suggests that many Americans did not perceive abortion as morally wrong." 32

At the turn of the century, abortion rates still remained high. ${ }^{33}$ State statutory restrictions on abortion remained basically unchanged until the 1960 s. $^{34}$ Physicians were allowed to perform abortions "only to preserve the mother's life;" therefore, most abortions were performed illegally. ${ }^{35}$ This led to injury and death of many women who went to these illegal, unqualified abortionists. ${ }^{36}$ The medical practitioners, who had previously lobbied for strict abortion laws, became receptive to the idea that abortions should be performed legally in hospitals to prevent additional deaths. ${ }^{37}$

The problems of illegal abortion and the emergence of the women's movement led to the Abortion Reform Movement from 1960 to 1972 . $^{38}$ Reacting to changing public opinion, the American Law Institute ${ }^{39}$ drafted the Model Penal Code' ${ }^{40}$ proposed revisions to state abortion laws. ${ }^{41}$ After 1966,

and "nativist fears," because elite Protestant women often sought abortions. Id. These views have now been found to be parochial and have been rejected by today's organized medicine. Id.

28. Id. at 15. In 1830, Connecticut became the first state to punish abortion after quickening. RUBIN, supra note 16, at 13. Quickening is the "first motion felt in the womb by the mother of the fetus." BLACK's LAW DictionaRY, supra note 3, at 1282.

29. RuBIN, supra note 16 , at 15.

30. Id. at 14 .

31. Id.

32. Id.

33. Id. at 18. The abortion rate ranged from "one pregnancy in seven ... to one in three in 1936." Id.

34. Id. However, in the 1940 s, discussions about abortion began to take place. Id. at 36 . Articles were written on the subject in medical and law journals, and conferences were held to discuss "[t]he [a]bortion [p]roblem." Id. at 36-37.

35. Id. at 18. Legal restrictions only made abortions "furtive, humiliating, and dangerous." Id.

36. Id. at 45 .

37. Id.

38. See id. Abortion rights became one of the issues over which feminists of the women's movement rallied. Id. Feminists argued that it was a woman's right to exercise control over her body, not the government's right. Id.

39. The American Law Institute (ALI) is an organization of legal scholars that studies state laws and proposes changes. Id. at 79.

40. The Model Penal Code is a "proposed criminal code ... used as the basis for criminallaw revision by many states." BLACK'S LAW DICTIONARY, supra note 3, at 1025.

41. See JUDGES, supra note 5, at 107-08.

The code proposed to legalize abortion in certain circumstances: if continuing the pregnancy would gravely impair the pregnant women's mental or physical health; if the child would be born with a grave physical or mental defect; or if the 
a number of states began liberalizing their abortion laws. ${ }^{42}$ By 1971 , fourteen states had revised their abortion laws to permit abortions under certain circumstances. $^{43}$ However, in the majority of states, abortion remained a crime. $^{44}$

In 1973, abortion laws in the United States dramatically changed with the Supreme Court's decision in Roe v. Wade. ${ }^{45}$ In Roe, the Court held that a "state criminal abortion statute . . . that excepts from criminality only a life-saving procedure on behalf of the mother ... is violative of the Due Process Clause of the Fourteenth Amendment." 46 The Court then defined the stages where abortion can be regulated. ${ }^{47}$ The Court made abortion legal when obtained prior to the end of the first trimester, leaving the decision to the medical judgment of the pregnant woman's attending physician. ${ }^{48}$ The Court allowed the state, in promoting its interest in the health of the mother, to reasonably regulate the abortion procedure subsequent to the end of the first trimester. ${ }^{49}$ For the stage subsequent to viability, the Court authorized states to regulate and even prohibit abortion. ${ }^{50}$

In 1989, the Supreme Court decided Webster v. Reproductive Health Services. ${ }^{51}$ For the first time since Roe, the Court allowed the state to regulate

pregnancy resulted from rape, incest, or illicit intercourse with a girl under the age of sixteen.

Id. These proposals had a major influence on legislation in reforming states. Id.

42. Id. A number of reformed states regarded the Model Penal Code as a blueprint for their own legislation. RuBIN, supra note 16, at 79.

43. RUBIN, supra note 16 , at 117 . The circumstances that the states allowed for abortion include the following: avoiding harm to the woman's physical or mental health, allowing abortion if the fetus would have been born with serious mental or physical handicap, and allowing abortion for rape or incest cases. See JUDGES, supra note 5, at 108.

44. RUBIN, supra note 16 , at 117.

45. Jane Roe, an unmarried pregnant woman, wished to terminate her pregnancy by an abortion performed by a "competent, licensed physician, under safe, clinical conditions." Roe, 410 U.S. at 120 . Roe was unable to get an abortion in Texas because her life was not threatened by the continuation of her pregnancy, and because she was unable to afford to travel to another state where abortion was legal. Id. Roe claimed the Texas statutes were unconstitutionally vague and restricted her right to privacy. Id.

46. Id. at 164 . The Due Process Clause is "[t]he constitutional provision that prohibits the government from unfairly or arbitrarily depriving a person of life, liberty, or property." BLACK'S LAW DICTIONARY, supra note 3, at 539; see U.S. Const. Amend XIV § 1. Roe established "a federal constitutional right to abortion, and thus made every state law on abortion subject to federal judicial review for compliance with the standards ...." JUDGES, supra note 5, at 109. Since the 1973 decision, federal courts have been at the center of the abortion controversy. Id.

47. Roe, 410 U.S. at 164-65.

48. Id. at 164; see also JUDGES, supra note 5, at 145.

49. Roe, 410 U.S. at 164; see also JUDGES, supra note 5, at 145.

50. Roe, 410 U.S. at 164-65; see also JUDGES, supra note 5, at 145 . A viable fetus is a fetus that is capable of living outside the womb. BLACK's LAW DICTIONARY, supra note 3, at 1597.

51. 492 U.S. 490 (1989). State-employed health care professionals and nonprofit corporations offering abortion counseling and services brought this class action challenging the constitutionality of a statute that regulated the performance of abortions. Id. at 500-01. 
abortion in the second trimester to protect fetal life rather than maternal health. ${ }^{52}$ Although the Court in Webster clearly changed direction on abortion rights, none of the five opinions in Webster had the binding force of precedent. ${ }^{53}$ Even so, this was the first time a majority of the justices upheld a statute that interferes with the doctor-patient relationship during the second trimester for reasons unrelated to maternal health. ${ }^{54}$ This decision is plainly contrary to the trimester framework that the Court established in Roe. ${ }^{55}$ Therefore, although not precedent, the law obviously changed when Webster was decided. ${ }^{56}$

In 1992, the Supreme Court decided Planned Parenthood Southeastern Pennsylvania v. Casey. ${ }^{57}$ The Court in Casey did not expressly overrule Roe. ${ }^{58}$ Instead, the justices redefined $R o e$ and "tried to articulate a new constitutional standard for abortion rights." 59 The Court created a new standard in testing the constitutionality of state abortion restrictions. ${ }^{60}$ The Court held that the undue burden test, rather than the trimester framework, should be used in evaluating state's abortion restrictions before viability. ${ }^{61}$ The Court's decision in Casey gave abortion rights a "much smaller scope" than abortion rights in Roe. ${ }^{62}$ The undue burden test invited states to impose various measures to restrict abortions, provided that the measures do not "act directly, openly, and straightforwardly to protect previability fetal life."

52. Id. at 519-20. There were seventy-eight amicus briefs in the Webster case. RUBIN, supra note 16; at 10 . Of those seventy-eight, forty-five briefs supported an anti-abortion position. Id.

53. See JUDGES, supra note 5, at 212 . It takes five justices to join an opinion that binds the Court in later cases; therefore, the Court did not expressly overrule Roe $v$. Wade, including its trimester framework. Id.

54. Id. The statute specified that before performing an abortion on any woman in her second trimester (twenty or more weeks pregnant), the physician must ascertain whether the fetus is viable. Webster, 492 U.S. at 500.

55. JUDGES, supra note 5 , at 212 .

56. Id.

57. 505 U.S. 833 (1992). Five abortion clinics and one physician brought this suit, claiming provisions of a Pennsylvania statute were unconstitutional. Id. at $844-45$. The statute required informed consent of the woman seeking the abortion, and required that she be provided with certain information at least twenty-four hours before the abortion. Id. at 844 (emphasis added). The statute also required informed consent of one parent when seeking an abortion for a minor and required a married woman to notify her husband before an abortion would be performed. Id.

58. JUDGES, supra note 5, at 221. The Court upheld Roe's essential holding, under the doctrine of stare decisis, recognizing a woman's right to choose an abortion before viability without undue interference from the State. Casey, 505 U.S. at 845-46.

59. JUDGES, supra note 5, at 221.

60. Id. at 224.

61. Casey, 505 U.S. at 873-78; see also JUDGES, supra note 5, at 224. "Undue burden" is defined as "ha[ving] the effect of placing a substantial obstacle in the path of a woman's choice." Casey, 505 U.S. at 877; accord JUDGES, supra note 5, at 224.

62. JUDGES, supra note 5, at 224.

63. See id. at 226. 
informed consent requirements, the twenty-four hour waiting period, and the parental consent of a minor did not impose an undue burden. ${ }^{64}$ However, spousal notification did impose an undue burden. ${ }^{65}$

In 2000, the Court again considered the right to an abortion in Stenberg $v$. Carhart. $^{66}$ In Carhart, the Court held that a Nebraska statute violated the Constitution for two independent reasons. ${ }^{67}$ First, the statute lacked any exception for the preservation of the health of the mother. ${ }^{68}$ Second, the statute imposed an undue burden on the woman's ability to choose one type of partial birth abortion, thereby unduly burdening the right to choose abortion itself. ${ }^{69}$

\section{B. The Consequences of Those Laws on the Citizens and the United States}

The rate of legal abortions practically doubled after the Supreme Court's decision in Roe. ${ }^{70}$ In 1992, according to the Alan Guttmacher Institute, ${ }^{71}$ there were over 1,500,000 abortions performed in the United States. ${ }^{72}$ After Roe, the majority of those abortions were performed early in pregnancy - during the first

64. Casey, 505 U.S. at 881-87.

65. Id. at $887-98$.

66. 530 U.S. 914 (2000). A physician who performed abortions brought suit, challenging the constitutionality of a Nebraska statute banning partial birth abortion. Id. at 921-22.

67. Id. at 930.

68. Id.

69. Id. There are two types of partial birth abortion: D and E, and D and X. Jan Crawford Greenberg, Online NewsHour: A Summary of Partial-Birth Arguments Before the High Court (transcript of PBS television broadcast, April 25, 2000), at http://www.pbs.org/ newshour/bb/law/jan-june00/scotus_4-25.html (last visited Oct. 13, 2004). 'In 'D and E,' you are classically breaking up the fetus within the uterus and taking out one piece at a time. With a 'D and $\mathrm{X}$,' you are trying to remove the fetus intact, or at least as intact as possible ....' Id. (quoting Dr. Leroy Carhart). The Court held that the statute applied to both procedures. Carhart, 520 U.S. at 938 . Because D and E is commonly used, it places a substantial obstacle in the path of a woman seeking an abortion before viability. Id.

70. JUDGES, supra note 5, at 30 . It is estimated that approximately one million legal abortions were performed in 1975. Id. Between 1973 and 2002, it is estimated that 43,358,592 abortions were performed in the United States. Minnesota Citizens Concerned for Life, Abortion Facts - U.S. Statistics and Information, at http://www.mccl.org/abortion_facts.htm (n.d.) (on file with author) [hereinafter Abortion Facts].

71. The Alan Guttmacher Institute is a special research affiliate to Planned Parenthood. Abortion Facts, supra note 70.

72. Id. The Centers for Disease Control (CDC) reports that approximately $1,300,000$ abortions were performed in 1992. Id. The Guttmacher Institute reports higher numbers than the CDC because Guttmacher actively collects the abortion data directly from providers, such as Planned Parenthood. Id. The CDC, on the other hand, relies on figures gained from voluntary reporting by abortion providers relayed to the CDC from state health agencies. Id. The CDC's statistics are also low because they stopped including statistics from four states including California, Alaska, New Hampshire and Oklahoma. Abortion Facts, supra note 70; see also CDC's Reproductive Health Information Source, Surveillance and Research, Fact Sheet, Abortion Surveillance 1999, at http://www.cdc.gov/nccdphp/drh/surv_abort99.htm (last modified May 22, 2003) (last visited Sept. 25, 2004) [hereinafter Surveillance]. In 1997, California accounted for twenty-three percent of the nation's abortions. Abortion Facts, supra note 70 . 
twelve weeks of pregnancy. ${ }^{73}$ Since 1973 , the trend has been toward a larger percentage of abortions being performed earlier in pregnancy. ${ }^{74}$

Before Roe, forty-four percent of women went out of state to have their abortions and most of those abortions were performed in hospitals. ${ }^{75}$ By 1985 , ninety-two percent of women who had abortions obtained them within their own state of residence, and eighty-three percent of abortions were performed in a clinical setting. ${ }^{76}$

The legalization of abortion in Roe led to a dramatic decline in backalley, illegal abortions. ${ }^{77}$ It is estimated that before $1973,1.2$ million women had illegal abortions each year. ${ }^{78}$ The Guttmacher Institute reports that complications from abortions occur in less than one percent of cases, and a woman is "statistically less likely to experience complications from an abortion than from a penicillin shot.",79

In the 1940s, the Centers for Disease Control (CDC) estimated there were 1,000 abortion-related deaths per year. ${ }^{80}$ From 1979 to 1985 , the rate of deaths related to legal abortions was less than one death per 100,000 abortions. ${ }^{81}$ In 1998 , the CDC reported nine maternal deaths related to legally induced abortion. ${ }^{82}$

The decision-making process for women in the United States who choose to have an abortion is not black and white. One study found that, for many women, the decision to have an abortion is complex and involves many factors. ${ }^{83}$ The factors most frequently mentioned are: concern that having a baby will change the woman's life; inability to afford a child at that time; problems in the relationship with the father; not wanting to be a single parent; not ready for the responsibility of parenthood; not wanting others to know that the woman was pregnant or sexually active; and not being psychologically mature or chronologically old enough for a child. ${ }^{84}$ Women in the study indicated the two most important reasons that led to the ultimate decision of having an abortion were not being able to afford a child and not being ready to

73. JUDGES, supra note 5 , at 33 . In $1973,85.4 \%$ of abortions were performed in the first trimester. Id.

74. Id. In 1999, eighty-eight percent of abortions were performed in the first twelve weeks of pregnancy. Surveillance, supra note 72.

75. Abortion and the States: Polttical Change and Future Regulation 84 (Jane B. Wishner ed., 1993) [hereinafter Political ChaNGE].

76. Id.

77. See Feminist Majority, Feminist Court Watch, Roe v. Wade: Legalizing Abortion, at http://www.feminist.org/courts/roe.asp (n.d.) (last visited Sept. 25, 2004).

78. Id.

79. Id.

80. Political Change, supra note 75 , at 109.

81. Id. at 87.

82. Surveillance, supra note 72.

83. JUDGES, supra note 5, at 37 . This Alan Guttmacher Institute study examined data from 1,900 abortion patients. Id.

84. Id. at 37-38. 
have a child. ${ }^{85}$ A Guttmacher study in 2000 reported that seventy-five percent of women had an abortion because having a baby would interfere with their work, school, or other responsibilities. ${ }^{86}$ Less than two percent of women have abortions because they were raped or because of incest. ${ }^{87}$

Studies have shown that women in the United States are subsequently affected by their abortions. A 1985 study researched "long-term manifestations of abortion" and found that eighty-one percent of women who had abortions reported "preoccupation with their aborted child." ${ }^{, 88}$ The study also reported: " $54 \%$ had nightmares; $35 \%$ had hallucinations of visitations with their child; and 96\% felt their abortion had taken a human life." found that seventy-eight percent of Americans agree that women who have abortions experience emotional trauma, such as grief and regret. ${ }^{90}$

\section{The Abortion Laws Today}

Today, the topic of debate is the banishment of partial birth abortion. ${ }^{91}$ On June 4, 2003, the House of Representatives ${ }^{92}$ overwhelmingly approved legislation to outlaw partial birth abortion. ${ }^{93}$ The Senate ${ }^{94}$ voted to approve the bill on October 21, 2003. ${ }^{95}$ On November 5, 2003, President George W. Bush signed into law the first federal restriction on abortion in thirty years. ${ }^{96}$ Less than an hour later, a federal judge in Nebraska partially blocked the implementation of the law. ${ }^{97}$ The next day federal judges in New York and

85. Id. at 38.

86. Abortion Facts, supra note 70.

87. Id.

88. Roe v. Wade 27 Years of Life Denied, Abortion's Consequences, at http://www.roevwade.org/consequences.html (n.d.) (last visited Oct, 14, 2004). This study was performed by Dr. Anne Speckhard at the University of Minnesota in 1985. Id.

89. Id.

90. Abortion Facts, supra note 70.

91. Robin Toner, Measure Banning Abortion Method Wins House Vote, N.Y. ToMEs, June 5, 2003, at A1. Partial birth abortion is a type of abortion used in the second and third trimester. Id. The procedure involves "delivering the lower part of the fetus's body, puncturing and collapsing its head while still inside the women's body, and the delivery of a dead, but largely intact fetus." Id.

92. The House of Representatives is "[t]he lower chamber of the U.S. Congress, composed of 435 members - apportioned among the states on the basis of population - who are elected to two-year terms." BLACK's LAW DICTIONARY, supra note 3, at 757.

93. Toner, supra note 91 . The vote was 282-to-139. Id. In the last eight years, Congress had twice passed similar bills, but President Clinton vetoed both of them. Id.

94. The Senate is " $t]$ he upper house of the U.S. Congress, composed of 100 members two from each state - who are elected to six-year terms." BLACK's LAW DICTIONARY, supra note 3, at 1392.

95. Jim Abrams, Senate Approves Ban on Abortion Procedure, N.Y. SUN, Oct. 22, 2003, at 4. The vote was sixty-four to thirty-four. Id.

96. Ron Hutcheson, Abortion Restriction Signed into Law; Legal Challenges Already Under Way, KNIGHT RIDDER WASH. BUREAU, Nov. 6, 2003.

97. Id. In Lincoln, Nebraska, U.S. District Judge Richard Kopf issued a temporary 
California also blocked the law. ${ }^{98}$ All three rulings prevent enforcement of the ban until a challenge to the law's constitutionality can be heard. ${ }^{99}$ The U.S. Department of Justice is now reviewing the block in New York. ${ }^{100}$ The Justice Department requested an evidentiary hearing to justify the earlier findings of Congress, which stated that partial birth abortions are not medically necessary and are inhumane. ${ }^{101}$

Supporters of this bill call the partial birth procedure "barbaric."102 On the other hand, opponents of the bill argue that the partial birth procedure is so broad that the bill could end up criminalizing many types of abortions that are medically necessary. ${ }^{103}$ The two sides differ widely on the frequency of partial birth abortions and on the definition of partial birth abortion, which is not a medical term. ${ }^{104}$ Under the bill, physicians who perform partial birth abortions are subject to fines and up to two years of imprisonment. ${ }^{105}$ Women who undergo the procedure are not subject to prosecution, but their husbands or their parents, in cases involving minors, could sue the doctor for damages. ${ }^{106}$ The American Civil Liberties Union ${ }^{107}$ has announced its plans to legally challenge the ban to protect women and doctors. ${ }^{108}$

Another historic turn of events happened on June 17, 2003, when Norma McCorvey, also known as "Roe," filed a motion to re-open her case, Roe $v$. Wade, and requested that it be overturned. ${ }^{109}$ McCorvey petitioned the court to

restraining order, citing concerns that the law lacked any health exception. Terence Hunt, Bush Signs Partial-Abortion Bill, THE BarRe MONTPILlier TIMES ARguS, Nov. 5, 2003, http://www.timesargus.com/apps/pbcs.dll/article?AID=/20031105/NEWS/31 1050345\&SearchI $\mathrm{D}=731830206765$.html (last visited Oct. 13, 2004).

98. Judges in 2 More States Block New Abortion Law, INDIANAPOLIS STAR, Nov. 7, 2003, at Nation/World, News in Brief, http://www.indystar.com/articles/5/090515-8405-010.html (last visited Oct. 13, 2004). Manhattan U.S. District Judge Richard Casey's ruling affects a majority of the abortion providers in the United States. Id. The ruling in San Francisco affects doctors who work at 900 Planned Parenthood clinics nationwide. Id.

99. Id.

100. U.S. Justice Department Wants Block on Partial-Abortion Ban Reviewed, Channel News Asia, Nov. 11, 2003, http://www.channelnewsasia.com/stories/health/view/56671/1/html (on file with author).

101. Id.

102. Toner, supra note 91.

103. See id. Senator Barbara Boxer (D-Cal.) stated that " $[\mathrm{t}]$ his is indeed a historic day, because for the first time in history Congress is banning a medical procedure that is considered medically necessary by physicians." Abrams, supra note 95.

104. Abrams, supra note 95.

105. Id.

106. Hutcheson, supra note 96.

107. The American Civil Liberties Union is a nonprofit, nonpartisan organization that "defend[s] and preserve[s] the individual rights and liberties guaranteed to all people in this country by the Constitution and laws of the United States." American Civil Liberties Union, About Us, at http://www.aclu.org/about/aboutmain.cfm (n.d.) (last visited Sept. 25, 2004).

108. American Civil Liberties Union, Federal Ban on Safe Abortion Procedures Deceptive and Dangerous, ACLU Promise Lawsuit to Protect Women and Doctors, at http://www.aclu. org/news/NewsPrint.cfm?ID=13656\&c=148 (Sept. 17, 2003) (last visited Oct. 13, 2004).

109. LifeSite Daily News, 'Roe' of 'Roe vs. Wade' Files Motion to Re-Open Landmark Abortion Case, at http://www.lifesite.net/ldn/2003/jun/030617a.html (June 17, 2003) (last 
re-open her original case based on changes in factual conditions and changes in the law. ${ }^{110}$

The controversial issue of abortion brings other cases to the courts, cases that do not focus on the woman's right to an abortion. Two recent U.S. Supreme Court cases involve the right for anti-abortionists to protest outside health facilities that perform abortions. ${ }^{111}$ Other controversial cases involve the prosecution of the killing of abortion doctors and the bombing of abortion clinics. ${ }^{12}$ Needless to say, abortion centered case law continues to test the limits of the judicially mandated abortion rights.

\section{The Possibility of Abortion Laws in the Future}

The future of abortion in the United States will continue to be a controversial issue. "Although polls show that across America people are generally opposed to abortion, they do not believe that legislation should be introduced to make it illegal."13 A 1999 Gallup Poll found that sixteen percent of Americans believe abortion should be legal for any reason at any time during a woman's pregnancy and fifty-five percent believe abortion should be legal only to save the life of the mother or in cases of rape or incest. ${ }^{114}$ A 2003 Gallup Poll reports that eighty-eight percent of Americans favor a law requiring physicians to inform abortion patients about alternatives to abortion. ${ }^{115}$

visited Oct. 13, 2004).

110. Id.

Using Rule 60 [of the Federal Rules of Civil Procedure], there are three major arguments to re-open and overturn the case on the basis of changed facts and law: 1. Norma McCorvey, and more than 1,000 women who have actually had abortions, have signed affidavits that attest to the devastating emotional, physical, and psychological trauma of abortion. These affidavits are the largest body of sworn evidence in the world on the negative effects of abortion on women. It is more than a thousand times more evidence from women than the Court heard in Roe. 2. The unanswered question in Roe's former case, "when does life begin?" was treated by the Court as a philosophical question when the case was first heard in 1973. Since then, an explosion of scientific evidence on human life conclusively answers the question that life begins at conception. 3 . The state of Texas in 1999 enacted a law in which it agreed to provide for any woman's unwanted child from the child's birth to 18 years of age with no questions asked. Legally, because the state has agreed to take responsibility for all unwanted children, women should no longer be forced to dispose of "unwanted" children by ending a human life. Forty states have similar Baby Moses laws.

Id.

111. Cloer v. Gynecology Clinic, Inc., 528 U.S. 1099 (2000); Hill v. Colorado, 530 U.S. 703 (2000).

112. United States v. Waagner, 319 F.3d. 962 (7th Cir. 2003); United States v. Marra, 165

F. Supp. 2d. 478 (W.D.N.Y. 2001).

113. Tim Reid, Where a Woman's Rights Confront Religious Might, TMES (London), Sept. 4,2003 , at 3 .

114. Women's Issues, Abortion Statistics, at http://womensissues.about.com/cs/abortion stats/a/aaabortionstats_p.htm (n.d.) (last visited Sept. 25, 2004).

115. Abortion Facts, supra note 70. 
Given its divisive nature, abortion has always been and will always be a political issue. ${ }^{16}$ Although President Bush opposes abortion and supports legislation ending partial birth abortion, the President has backed away from opposing Roe v. Wade. ${ }^{117}$ However, opponents of the partial birth abortion ban warn that the approval of the bill was the "first step toward overturning the 1973 Court ruling." 118 There is also a possibility of a shift in balance in the Supreme Court, which could tip the Court against Roe v. Wade. ${ }^{119}$

\section{ABORTION IN IRELAND}

\section{A. Historical Aspect}

In Ireland, abortion has been illegal since $1861 .{ }^{120}$ Articles 58 and 59 of the Offenses Against The Person Act made abortion a criminal offense. ${ }^{121}$ Under the 1861 Act, the woman who has the abortion and anyone who helps her have that abortion are both liable for severe penalties. ${ }^{122}$ This Act could be amended at any time, and there is nothing in Ireland's Constitution to prevent

116. See Reid, supra note 113.

117. See supra note 96 and accompanying text; see also Reid, supra note 113.

118. Abrams, supra note 95 (quoting Senator Tom Harkin (D-Iowa)).

119. Reid, supra note 113. "At least two retirements are expected in two years, setting up a bitterly contested appointments battle if $\mathrm{Mr}$.] Bush achieves a second term and seeks conservative replacements." Id.

120. Irish Family Planning Association, Abortion Law in Ireland - A Brief Summary, at http://www.ifpa.ie/campaigns/abortion/hist.html (n.d.) (last visited Sept. 26, 2004) [hereinafter Abortion Law in Ireland].

121. Id. Article 58 states:

Every woman, being with child, who, with intent to procure her own miscarriage, shall unlawfully administer to herself any poison or other noxious thing, or shall unlawfully use any instrument or other means whatsoever with the like intent, and whosoever, with intent to procure the miscarriage of any woman, whether she be or be not with child, shall unlawfully administer to her or cause to be taken by her any poison or other noxious thing, or shall unlawfully use any instrument or other means whatsoever with the like intent, shall be guilty of felony, and being convicted thereof shall be liable . . . to be kept in penal servitude for life....

Art. 58, Offenses Against the Person Act, 1861, http://members.aol.com/abtrbng/oatpa61.htm (last visited Sept. 26, 2004); see also Abortion Law in Ireland, supra note 120. Article 59 states:

Whosoever shall unlawfully supply or procure any poison or other noxious thing, or any instrument or thing whatsoever, knowing that the same is intended to be unlawfully used or employed with intent to procure the miscarriage of any woman, whether she be or be not with child, shall be guilty of a misdemeanor, and being convicted thereof shall be liable ... to be kept in penal servitude.

Art. 59, Offenses Against the Person Act, 1861, http://members.aol.com/abtrbng/oatpa61.htm (last visited Sept. 26, 2004); see also Abortion Law in Ireland, supra note 120.

122. TOM Hesketh, The SECOND Partitioning Of IRELAND? ThE AbORTION ReFERENDUM of 1983,2 (1990). 
such an amendment. ${ }^{123}$ Nevertheless, this restrictive abortion legislation has remained virtually unchallenged for over one hundred years. ${ }^{124}$

In 1979, these provisions were confirmed by the Health (Family Planning) Act in Section 10. ${ }^{125}$ This Act made provisions to ensure contraceptives were available only for the purpose of family planning or for medical reasons. ${ }^{126}$ The Act also regulated the sale, importation, manufacturing, advertising, and displaying of contraceptives. ${ }^{127}$ Until 1979, artificial contraception was illegal. ${ }^{128}$ It was not possible to obtain a license to manufacture or sell contraception. ${ }^{129}$ Until the $1960 \mathrm{~s}$, it was common practice in Ireland for single women who became pregnant to be confined to convents where they did hard, household labor for the duration of their pregnancy and beyond. ${ }^{130}$ These women were obligated to give up their children for adoption. ${ }^{131}$

After the U.S. Supreme Court's decision in Roe v. Wade, anti-abortion activists feared the possibility that Irish courts would judicially create or recognize the right to abortion. ${ }^{132}$ The pro-life activists set up a pressure group, the "Pro-Life Amendment Campaign" (PLAC), to lobby for constitutional change. ${ }^{133}$ In opposition to the amendment, the "Women's Right to Choose Campaign" (WRCC) was formally launched in August, 1980. ${ }^{134}$ After much controversial debate ${ }^{135}$ on September 7, 1983, the people of Ireland voted to insert the Eighth Amendment into the Constitution, which became Article 40.3 .3 (known as the 1983 Referendum). ${ }^{136}$ Prior to the entry of this amendment, the Irish Constitution did not contain any specific provision on

123. See id.

124. Id. at 1 .

125. JAMES KINGSTON \& ANTHONY WhELAN, ABORTION AND THE LAW 53 (1997); see also Health (Family Planning) Act, 1979 section 10, http://www.irishstatutebook.ie/ZZA20Y 1979S 10.html (last visited Sept. 25, 2004).

126. Health (Family Planning) Act, 1979 section 4, http://www.irishstatutebook.ie/ZZA 20Y1979S4.html (last visited Oct. 13, 2004).

127. Id.

128. Ellie Lee et al., Ireland and Abortion: Abortion Law and Politics Today, Pro+Choice Forum, at http://www.prochoiceforum.org.uk/ireland2.asp (n.d.) (last visited Oct. 13, 2004).

129. Id.

130. THE Abortion PaPERS, Ireland 21 (Ailbhe Smyth ed., 1992) [hereinafter ABORTION PAPERS].

131. Id.

132. KINGSTON \& WHELAN, supra note 125 , at 4 .

133. Id.

134. See HESKETH, supra note 122 , at 72.

135. See generally id. The debate reached unprecedented heights of controversy for Ireland when the PLAC headquarters was damaged in a fire. Id. at 364.

136. Art. 40.3.3, Constitution of Ireland amend. VIII, 1983; see also KINGSTON \& WHELAN, supra note 125, at 5. Article 40.3.3 of the Constitution was amended to read as follows: "The State acknowledges the right to life of the unborn and, with due regard to the equal right to life of the mother, guarantees in its laws to respect, and, as far as practicable, by its laws to defend and vindicate that right." Abortion Law in Ireland, supra note 120. 
abortion. ${ }^{137}$ Before 1983 , no Irish court was ever asked to decide whether the Constitution either required the State to prohibit abortion or allowed women to obtain abortions; however, in dicta, individual members of the Supreme Court indicated that abortion was constitutionally prohibited and that any right to privacy protected by the Constitution did not encompass a general right to abortion. ${ }^{138}$ The intention of the 1983 Referendum was to "introduce an absolute ban on abortion into the constitution with the aim of preventing the legislature or the courts from ever liberalizing abortion on the grounds of personal privacy or the repeal of the 1861 Offenses Against the Person Act."139 The amendment was voted in by $66.45 \% .{ }^{140}$ Since its introduction to Ireland's constitution, it has been used to attack the civil and legal rights of women in Ireland. ${ }^{141}$

Following the insertion of the Eighth Amendment into Ireland's Constitution, a number of cases came before the Irish courts concerning its interpretation; ${ }^{142}$ however none directly raised the issue of the lawfulness of abortion under the amendment until 1992. ${ }^{143}$ That year the abortion issue in Ireland became "humanized" with the case, Attorney General v. $X{ }^{144}$ In the $X$ case, the High Court granted an injunction, preventing a pregnant fourteenyear-old rape victim from leaving Ireland to have an abortion in England. ${ }^{145}$ The defendant appealed, claiming she was suicidal at the thought of carrying her pregnancy to term. ${ }^{146}$ The Supreme Court reversed, holding that there was

137. KINGSTON \& WHELAN, supra note 125 , at 2 .

138. Id.

139. Dublin Abortion Rights Group, Consequences of the 1983 anti-abortion referendum in Ireland, at http://struggle.ws/darg/pr/conseq1983.html (n.d.) (last visited Oct. 13, 2004) [hereinafter Consequences]. The words were framed in December of 1982 by Dr. Michael Woods, Minister for Health. 20th Anniversary, supra note 7.

140. 20th Anniversary, supra note 7. The amendment was passed by a two to one majority. HESKETH, supra note 122, at 364.

141. Consequences, supra note 139; see also infra pp. 21-22 and notes 167-75.

142. See Attorney Gen. v. Open Door Counselling Ltd. \& Dublin Well-woman Ctr. Ltd., [1988] I.R. 593 (Ir. H. Ct.); Soc'y for the Prot. of Unborn Children (Ire.) Ltd. v. Coogan [1989] I.R. 734 (Ir. H. Ct.); Soc'y for the Prot. of Unborn Children (Ire.) Ltd. v. Grogan [1989] I.R. 753 (Ir. H. Ct.).

143. KINGSTON \& WHELAN, supra note 125 , at 6.

144. 20th Anniversary, supra note 7. After the High Court made its decision, thousands of protestors poured into the streets. Id. This case was one of the most important constitutional cases to come before the Irish court, and it has remained one of the most widely publicly debated and analyzed cases in Ireland's legal history. KINGSTON \& WHELAN, supra note 125, at 6. Sinead O'Connor traveled home to Ireland to lead students in a protest march, chanting "[k]eep your rosaries off our ovaries" on national television. CLEMENT LOSCHER, THE X CASE: HOW ABORTION WAS BROUGHT INTO IRELAND 81 (1992).

145. Attorney Gen. v. X [1992] I I.R. 1 (Ir. S.C.); see also Abortion Law in Ireland, supra note 120 . The offense was committed by a forty-one-year-old man, who was a family friend. KINGSTON \& WHELAN, supra note 125, at 6.

146. X [1992] 1 I.R. 1 (Ir. S.C.); see also 20th Anniversary, supra note 7. Prior to going to England, the defendant stated that she "wish[ed] it were all over. Sometimes I feel like throwing myself downstairs." KINGSTON \& WHELAN, supra note 125, at 7. 
a "real and substantial risk" of suicide if the pregnancy continued; therefore, the abortion was permissible, even in Ireland. ${ }^{147}$ However, the Court also held that where no such risk existed, both information and possibly travel could be prevented in the interest of safeguarding the right to life of the "unborn."148 A clinical psychologist was of the opinion that the "psychological damage that would be suffered by $X$ if she continued her pregnancy would be 'considerable' and that the damage to her mental health would be 'devastating.",149

Although the proponents of the Eighth Amendment may have believed that inserting the amendment into the Constitution would prevent the judiciary or the legislature or both from legalizing abortion, the decision in the $X$ case created a new meaning for Article 40.3.3. ${ }^{150}$ The Court broadened the interpretation when it held that abortion is not only permitted by the Constitution in certain circumstances, but also that women are constitutionally entitled to have an abortion when it is necessary to protect their own right to life. ${ }^{151}$ Shortly after the $X$ case, two referenda were passed, amending Article 40.3.3 to safeguard the rights to travel and to acquire information. ${ }^{152} \mathrm{~A}$ third referendum was rejected that would have limited the effect of the $X$ case, by restricting the "real and substantial risk" test to cases where the risk to the pregnant woman's life was due to an illness or disorder and not to a risk of suicide. ${ }^{153}$

At the United Nations International Conference on Population and Development, in 1994, Ireland became one of 179 nations that affirmed "the basic right of all individuals to decide freely and responsibly the number and spacing of their children, including the right to make decisions concerning reproduction free of discrimination, coercion and violence."154 Despite commitments such as these, ${ }^{155}$ the Irish government still prohibited abortion, except where the life of the mother is at risk. ${ }^{156}$

147. X [1992] 1 I.R. 1 (Ir. S.C.); see also Abortion Law in Ireland, supra note 120.

148. X [1992] 1 I.R. 1 (Ir. S.C.); see also Abortion Law in Ireland, supra note 120. This decision was surprising because it came through a judiciary that had "previously rendered conservative judgments in this area." LOSCHER, supra note 144, at 3.

149. KINGSTON \& WHELAN, supra note 125 , at 8 . The psychologist determined that there was a "risk" to the life of the defendant by suicide on the basis of a short examination approximately one hour. LOSCHER, supra note 144, at 21.

150. KINGSTON \& WHELAN, supra note 125 , at 34.

151. See id. at 35.

152. Abortion Law in Ireland, supra note 120. The travel referendum stated, "Subsection 3 of this section [Article 40.3.3] shall not limit freedom to travel between the State and another state." Id. The information referendum further stated that "Subsection 3 shall not limit freedom to obtain or make available ... information relating to services lawfully available in another state." Id.

153. Id.

154. Katherine Hall Martinez \& Christina Zampas, Ship Highlights Desire for Abortion Rights, NEwSDAY, July 23, 2001, http://www.crlp.org/tools/print_page.jsp.

155. This basic right was also affirmed by Ireland in 1986 when it became a party to the Convention on the Elimination of All Forms of Discrimination Against Women. Id.

156. Id. 
In 1998, the High Court was forced to look at the interpretation of the $X$ case in a similar situation known as the $C$ case. ${ }^{157}$ In the $C$ case, a thirteen-yearold rape victim remained in the care of the Eastern Health Board, which allowed her to receive free medical care including an abortion. ${ }^{158} \mathrm{C}$ sought permission in the courts to leave the jurisdiction to obtain a lawful abortion in England. ${ }^{159}$ The High Court ruled that $\mathrm{C}$ was entitled to leave the country to have an abortion because she was likely to take her own life if forced to continue with the pregnancy. ${ }^{160}$ This case demonstrated that the failure of the government to enact legislation following the $X$ case led to another young victim of rape having to go through the court process. ${ }^{161}$

In March 2002, by a very close margin, voters rejected a governmental plan to amend Ireland's abortion laws. ${ }^{162}$ For the referendum, a blanket "yes or no" vote was required for a number of separate issues. ${ }^{163}$ Two of the important issues on the abortion bill were: (1) "Should suicide be ruled out as grounds for allowing abortion?" and (2) "Should pregnant women whose health is threatened by their pregnancy be allowed to have an abortion in Ireland?"164 If not defeated, the referendum would have overturned the landmark decision in the $X$ case. $^{165}$ Instead, the rejected referendum left the judgment in 1992 in "legal limbo."166

\section{B. The Consequences of Those Laws on the Citizens and Ireland}

Once the 1983 Amendment was added to the Constitution, it was used to restrict other women's rights, besides restricting abortion, due to the lack of legislation clarifying its legal meaning. ${ }^{167}$ For example, ethics committees in some hospitals refused to provide pre-natal testing due to the ban on abortion

157. See A. \& B. v. E. Health Bd. [1998] 1 I.R. 464 (Ir. H. Ct.); see also Abortion Law in Ireland, supra note 120. 120.

158. A. \& B. [1998] 1 I.R. 464 (Ir. H. Ct.); see also Abortion Law in Ireland, supra note

159. Abortion Law in Ireland, supra note 120. C's father, who originally was supportive of $C$ 's decision to have an abortion, opposed the decision after speaking to the media and becoming influenced by extreme anti-abortion groups. Id.

160. A. \& B. [1998] 1 I.R. 464 (Ir. H. Ct.); see also Abortion Law in Ireland, supra note 120.

161. Abortion Law in Ireland, supra note 120.

162. Shawn Pogatchnik, Voters Defeat Ireland Abortion Bill, Associated Press, at http://www.nownj.org/njNews/2000-2002/Voters\%20Defeat\%20Ireland\%20Abortion\%20Bill .htm (Mar. 7, 2002) (last visited Oct. 13, 2004). The margin was $49.58 \%$ in favor and $50.42 \%$ against. Louise Williams, No Change to Abortion Laws, RADIO NETH. WERELDOMROEP, at http://www.rnw.nl/society/html/abortion020308.html (Mar. 8, 2002) (last visited Oct. 13, 2004).

163. Williams, supra note 162.

164. Id.

165. Pogatchnik, supra note 162.

166. Id.

167. See Consequences, supra note 139. 
because nothing could be done about any fetal abnormality discovered by the testing. ${ }^{168}$ Counseling services that gave information about abortion were closed down. ${ }^{169}$ Injunctions were brought against student unions that handed out information about abortion. ${ }^{170}$ In 1991, basic women's health books were removed from public libraries in Dublin because the books contained medical information about abortion. ${ }^{171}$ Advertisements for pregnancy-related services in British magazines were censored before the magazines went on sale in Ireland. ${ }^{172}$ "From 1983 onwards, every avenue of assistance through which women could travel to get abortion was systematically closed down."173

The 1983 Amendment also resulted in more battles through the courts on women's rights. ${ }^{174}$ The right to abortion information, the right to travel, and the right to crisis pregnancy counseling paid for by the state have all flowed from the 1983 referendum. ${ }^{175}$

After the $X$ case made abortion illegal, except in circumstances where the life of the mother was at risk, thousands of women sought abortions abroad, primarily in England. ${ }^{176}$ It is estimated that at least 6,000 women per year travel to Britain to obtain abortion services. ${ }^{177}$ This number does not include the women who cannot afford to travel abroad, who must seek abortions underground in unsanitary and unsafe conditions. ${ }^{178}$

The illegal status of abortion discouraged doctors from learning the abortion procedure. ${ }^{179}$ Physicians were further placed in a difficult position after the decision in the $X$ case. ${ }^{180}$ Because a pregnant woman had a constitutional right to an abortion if her life was at risk, a doctor would be legally required to perform the procedure. ${ }^{181}$ If a physician refuses to perform an abortion under such circumstances, he or she could face a civil suit on the

168. Id.

169. Lee, O'Brien \& Simpson, supra note 128.

170. Id.

171. Consequences, supra note 139.

172. Id.

173. Lee, O'Brien \& Simpson, supra note 128.

174. 20th Anniversary, supra note 7.

175. Id. See also Open Door Counseling Ltd. \& Dublin Well-woman Ctr. Ltd., [1988] I.R. 593 (Ir. H. Ct.); Coogan [1989] I.R. 734 (Ir. H. Ct.); Grogan [1989] I.R. 753 (Ir. H. Ct.).

176. Sarah Stephen, Ireland: Abortion ship offers women choice at http://www.greenleft. org.au/back/2001/452/452p25b.htm (2001) (last visited Oct. 13, 2004).

177. Women on Waves, at http://www.womenonwaves.net/ireland/news/about.html (n.d.) (last visited Sept. 26, 2004) [hereinafter Women on Waves]. The number is believed to be an underestimate because many women give English addresses to hide the fact that they are from Ireland. See THE ABORTION PAPERS, supra note 130, at 51.

178. Women on Waves, supra note 177. "Every year 20 million abortions worldwide are performed under illegal and unsafe conditions, resulting in the deaths of an estimated 70,000 women annually." Id. Unsafe methods lead to complications in about $40 \%$ of illegal abortion cases. Stephen, supra note 176.

179. Martinez \& Zampas, supra note 154.

180. See KingSTON \& WHELAN, supra note 125, at 24.

181. Id. 
ground of infringing a pregnant woman's constitutional right to life. ${ }^{182}$ If the woman died as a result of lack of treatment, the doctor could possibly face criminal prosecution. ${ }^{183}$

\section{The Abortion Laws Today}

Performing an abortion in Ireland remains illegal except in very limited circumstances; however, abortion information may be distributed in certain circumstances. ${ }^{184}$ Area health boards in Ireland have a duty to ensure that comprehensive family planning services are available, fulfilling this obligation in health centers through public health nurses, family doctors, and family planning organizations. ${ }^{185}$ In practice, advice and prescriptions for contraception are provided by family doctors, voluntary organizations, and private family planning clinics, even though such organizations are not required to do so. ${ }^{186}$

Furthermore, there remains an exception to the illegality of abortion where there is a real and substantial risk to the life of the mother, including a risk arising from a threat of suicide. ${ }^{187}$ However, the Medical Council ethical guidelines to doctors, while they recognize that a pregnancy may be terminated where there is a real and substantial risk to mother's life, do not accept that a threat of suicide presents such a risk. ${ }^{188}$ Therefore, in practice, pregnancies are terminated in hospitals where there is a substantial medical risk to the life of the mother, but are not terminated in cases of threat of suicide. ${ }^{189}$

Today, the number of women seeking pre-abortion counseling increases every year. ${ }^{190}$ In 2001 , the abortion ratio, calculated as the number of abortions per one thousand live births, was $115 .{ }^{191}$ It was estimated that 6,673 Irish women traveled abroad to obtain abortions. ${ }^{192}$ Of these women, approximately 940 were under the age of twenty, 4,900 were between the ages of twenty and thirty-four, and 760 were over the age of thirty-five. ${ }^{193}$

182. Id.

183. Id.

184. Oasis, Information on Public Services - an Irish Government resource, Family Planning Services in Ireland, at http://www.oasis.gov.ie/health/womens_health/family planning_services.html (n.d.) (last visited Sept. 26, 2004) [hereinafter Family Planning Services].

185. Id. Guidelines from the Department of Health and Children state that each health board should provide a leaflet that outlines the type and range of family services available in its area. Id.

186. Id.

187. Id.

188. Id.

189. Id.

190. 20th Anniversary, supra note 7.

191. William Robert Johnston, Historical abortion statistics, Ireland, at http://johnston sarchive.net/policy/abortion/ab-ireland.html (n.d.) (last visited Sept. 26, 2004).

192. Id.

193. Irish Family Planning Association, Irish Abortion Statistics, at http://www.ifpa.ie/ 
In response to illegal and unsafe abortions worldwide, the Women on Waves Foundation ${ }^{194}$ developed a reproductive health clinic on board a Dutch ship. ${ }^{195}$ The ship is fully equipped to offer contraceptives, information, training, workshops, and safe and legal abortions outside territorial waters in countries where abortion is illegal, such as Ireland. ${ }^{196}$ When Women on Waves announced that its first voyage would be to Ireland in June 2001, nearly two hundred women made appointments to obtain abortions in only four days. ${ }^{197}$ The overwhelming response revealed that women who are physically and financially able to travel overseas to obtain abortions represent a small fraction of women who would use abortion services if they were legal. ${ }^{198}$ Licensing problems prevented the ship's staff from providing any abortions to Irish women; however, the media coverage of the floating clinic informed the world that Irish women want access to safe, legal abortions. ${ }^{199}$

In 2003, twenty asylum-seeking women were granted temporary exit and re-entry visas to travel to Britain for abortions. ${ }^{200}$ These temporary visas were granted only as an "extremely exceptional" measure. ${ }^{201}$ Many women who were in the asylum process and who had a crisis pregnancy risked their applications by "sneak[ing] out of the country and back again to have abortions."202

\section{The Possibility of Abortion Laws in the Future}

It is still not clear whether the defeat of the 2002 referendum means that abortion in some circumstances is acceptable to the majority. ${ }^{203}$ Pro-choice

abortion/iabst.html (n.d.) (last visited Sept. 26, 2004). These statistics are based on official British statistics compiled by the UK Office for National Statistics. Id. These numbers do not include Irish women who did not give an address. Id.

194. Women on Waves is a non-profit organization based in the Netherlands. Women on Waves, supra note 177 . The group is committed to assisting women with unwanted pregnancies who live in countries where abortions are illegal. Id.

195. Id.

196. Id. The abortions on the ship are legal because the ship's doctors are acting under Dutch law, which allows abortion. Stephen, supra note 176. "The Netherlands has a very liberal abortion law, yet it has one of the lowest reported abortion rates in the world." Martinez \& Zampas, supra note 154 . "This is due to a comprehensive reproductive-health program that includes universal sex education in schools and easily accessible family-planning services, including emergency contraception." Id.

197. Martinez \& Zampas, supra note 154.

198. Id.

199. Id. Because the necessary Dutch medical license was not obtained, the crew could have faced up to four and a half years in jail and a large fine. Karen Birchard, Abortion Boat Faces Legal Complications, 357 THE LANCET 9273, (2001), http://www.thelancet.com/journal/ vol357/iss9273/full/llan.357.9273.news.16710.5 (last visited Oct. 13, 2004).

200. Kitty Holland, Asylum-seekers granted visas for UK abortions, IRISH TTMES, Aug. 30 , 2003, at 4. The Department of Justice indicates that this is twice as many as last year. Id. Eight were granted in 2001, and two were granted in 2000. Id.

201. Id.

202. Id.

203. See 20th Anniversary, supra note 7. 
lobbyists favor this view. ${ }^{204}$ Whereas, the pro-life view believes that the referendum was defeated by "some small element of people against abortion." 205 The latter view believes that the pro-life sentiment is stronger among the people of Ireland. ${ }^{206}$ Because of this unsolved issue, there will probably be a sixth abortion referendum. ${ }^{207}$ This referendum should clarify the discrepancy between the $X$ case and Article 40.3.3. ${ }^{208}$ Alternatively, pro-choice groups seek legislation in line with the 1992 Supreme Court or seek the deletion of Article 40.3.3. ${ }^{209}$

The reasons women face crisis pregnancies need to be addressed. ${ }^{210}$ The Irish Family Planning Act and the Well Woman Centre both describe as "frightening" the numbers of well-educated women who do not know the basics about their own reproductive cycles and how to use contraception. ${ }^{211}$ Sex education in schools is also inadequate. ${ }^{212}$ In Ireland, too many pregnancies are regarded as "crisis pregnancies" because support for women facing "the prospect of unplanned motherhood is inadequate, if there at all."213

\section{ABORTION IN RUSSIA}

\section{A. Historical Aspect}

In contrast to both the United States and Ireland, abortion has been legal in Russia since $1920 .^{214}$ In fact, the former Soviet Union was the first government in history to make abortion legal. ${ }^{215}$ This legalization gave a pregnant Russian woman the option to terminate her pregnancy at state hospitals without cost. ${ }^{216}$ In 1936, Joseph Stalin, the dictator of the former Soviet Union, ${ }^{217}$ criminalized abortion for the purpose of raising the birthrate to

204. Id.

205. Id. This "small element" is the Mother and Child Campaign, led by Justin Barrett. Id.

206. Id.

207. Id.

208. See id.

209. Id. Catherine Heaney of the Irish Family Planning Association says that Article 40.3.3 "needs to be deleted" because it does not "deal with the reality of abortion in Ireland." Id.

210. Id.

211. Id.

212. Id.

213. Id.

214. Gender Politics AND Post-Communism, ReFlections from EASTERn EUROPE AND THE FORMER SOVIET UNION 310 (Nanette Funk \& Magda Mueller eds., 1993) [hereinafter GeNDER PoltTICs]; see also Julia O. Kotlyar \& Margaret P. Battin, Abortion in Russia, 7 U. UTAH J. UNDERGRADUATE RES. 1, 11 (1999), http://www.lib.utah.edu/epubs/undergrad/vol7/ kotlyar.html (last visited Oct. 13, 2004).

215. GENDER POLITICS, supra note 214, at 310.

216. Kotlyar \& Battin, supra note 214 , at 11.

217. Sergei Blagov, Population Decline, Economic Realities See Abortion Restricted in Russia, The Cybercast News Service, at http://www.cnsnews.com/ViewForeignBureaus.asp? 
create more workers and soldiers. ${ }^{218}$ During this time, illegal abortions escalated while Stalin's attempt to raise the birthrate failed. ${ }^{219}$ Russian women were not properly educated about contraception and family planning; therefore, pregnant women continued to rely on the familiar method of abortion. ${ }^{220}$ Because illegal abortions led to increases in infant and maternal mortality rates, ${ }^{221}$ abortion was "reliberalized" in $1955 .{ }^{222}$

Russia's abortion regulations have remained some of the most permissive in the world. ${ }^{223}$ In certain circumstances, there are no limits on abortions during the first twelve weeks of pregnancy. ${ }^{224}$ The Fundamentals of the Legislation on Public Health Care ${ }^{225}$ is the main law regulating a Russian woman's right to abortion. ${ }^{226}$ The Ministry of Health ${ }^{227}$ classifies abortion into three categories: abortion upon request, abortion for medical reasons, and abortion for social reasons. ${ }^{228}$ There are thirteen special circumstances called "social indicators" that allow women to obtain an abortion between the twelfth and twenty-second week of pregnancy. ${ }^{229}$ The Ministry of Health has defined those social reasons as follows:

the illness of the husband; the death of the husband; imprisonment of either wife or husband; unemployment of wife or husband; loss or restriction of parental rights due to court order; the woman's marital status; criminal origin of the pregnancy; inadequacy of living space; woman's status as

Page=LForeignBureauslarchivel200308LFOR20030828b.html (Aug. 28, 2003); see also Kotlyar \& Battin, supra note 214, at 11.

218. Kotlyar \& Battin, supra note 214 , at 11 . "Stalin made it clear that Soviet couples should produce workers and soldiers as vigorously as new Soviet industries were turning out trucks and steel beams." Birth Control in Russia, INT'L HERALD TRIB., Sept. 3, 2003, at 8 [hereinafter Birth Control].

219. Kotlyar \& Battin, supra note 214 , at 11.

220. Id.

221. Id.

222. GENDER PolITICS, supra note 214 , at 311 . It was reasoned that legalizing abortion was a "necessary evil to prevent the carnage of illegal abortions and to help keep women in the labor force." Kotlyar \& Battin, supra note 214, at 11. The ban was also lifted when Stalin died in 1953. See Blagov, supra note 217.

223. See Steven Lee Myers, Russia Retreats from 50 Years of Permissive Law; Abortion on Demand/Once a Favored Birth Control Method, INT'L HeRALD TrIB., Aug. 26, 2003, at 2.

224. Id.

225. Russia's legislature passed the Fundamentals of Legislation on Public Health Care in 1993 in an effort to realize its commitment to public health. WOMEN OFTHE WORLD: LAWS AND Policies AfFecting Their RePRoductive Lives 156 (The Center for Reproductive Law and Policy ed., 2000) [hereinafter LAwS AND POLICIES]. The objective of the "Fundamentals" is to "guarantee the right to healthcare, to public health, and to medical and social assistance." Id. 226. Id. at 160 .

227. The Ministry of Health is the principal implementing agency of Russia's health care system. Id. at 156. The Ministry of Health has the duty of supervising and implementing national health programs. Id.

228. Id. at 157.

229. Myers, supra note 223, at 2. 
migrant or forced migrant; existence of three or more children; disability of a child; or income below the regional poverty line. ${ }^{230}$

Pregnancies can be terminated at any point for medical reasons, including severe disabilities of the fetus or threat to the mother's life. ${ }^{231}$

The punishment for performing an illegal abortion is regulated by the Criminal Code of the Russian Federation. ${ }^{232}$ An unauthorized individual without any medical education who performs an abortion is subject to a fine and mandatory community work of 100 to 240 hours. ${ }^{233}$ Repeat offenders can face imprisonment up to two years. ${ }^{234}$ If an illegal abortion results in the harm or loss of life of the woman, the general Criminal Code provisions for assault and murder would apply. ${ }^{235}$ Additionally, a licensed physician who performs an illegal abortion that leads to serious harm or death of the woman can be suspended from the medical practice for up to three years. ${ }^{236}$

Abortion information is unregulated in Russia. ${ }^{237}$ Advertisements for private and commercial clinics can be found in newspapers and magazines. ${ }^{238}$ Adolescents over fifteen years of age have the right to give their informed consent for abortion. ${ }^{239}$ Those under fifteen years of age must have parental consent before obtaining an abortion. ${ }^{240}$

Although Russia's Constitution ${ }^{241}$ guarantees free health care, ${ }^{242}$ state support for abortion has been significantly reduced. ${ }^{243}$ In 1997 , the Communist-controlled Russian parliament cut off financing to family planning clinics, leaving some 400 clinics to subsist on local subsidies. ${ }^{244}$ Basic medical insurance also does not fully cover expenses for abortion upon request. ${ }^{245}$

230. LAWS AND POLICIES, supra note 225, at 160.

231. Myers, supra note 223, at 2; see also LAWS AND PolicIEs, supra note 225, at 160.

232. LAWS AND POLICIES, supra note 225, at 160.

233. Id.

234. Id.

235. Id.

236. Id.

237. Id. at 160 .

238. Id.

239. Id. at 167 .

240. Id.

241. The Constitution of the Russian Federation was adopted by referendum on December 12, 1993. LAWS AND POLICIES, supra note 225, at 153.

242. Art. 41 \& 1 KonsT. RF (1993), http://www.constitution.ru/en/10003000-01.htm (last visited Sept. 27, 2004). In 1993, the government funded family planning clinics, which distributed free contraceptives and provided medical care. Sharon LaFraniere, Russians Feel Abortion's Complications, WASHINGTON POST ForEIGN SERVICE, Feb. 22, 2003, at A16. On the average, Russian women bear just more than one child. Id.

243. LAWS AND POLICIES, supra note 225, at 157.

244. LaFraniere, supra note 242. Lawmakers at that time said a nation with a falling birth rate did not need to promote birth control. Id.

245. LAWS AND POLICIES, supra note 225, at 160. 
Abortion is free in state-funded facilities, but women still must pay for anesthesia. ${ }^{246}$ Most women choose to have abortions at private clinics because the standards of hygiene and care are higher; however women must pay for these expensive services on their own. ${ }^{247}$

\section{B. The Consequences of Those Laws on the Citizens and Russia}

The permissive abortion laws have made abortion in Russia a common and widely accepted means of birth control. ${ }^{248}$ About sixty percent of all pregnancies in Russia end in abortion. ${ }^{249}$ This gives Russia one of the highest abortion rates in the world. ${ }^{250}$

During the Soviet Union era, women had limited options for avoiding pregnancy. ${ }^{251}$ On August 1, 1971, a Health Ministry's order permitted birth control pills for medical use, such as the treatment of endometriosis or hormonal disorders. However, its use was limited to medical use because of its alleged carcinogenic side effects. ${ }^{252}$ Contraceptives were so scarce and of such poor quality that "the dangers of crude, assembly-line abortions seemed the safer bet." 253 The Health Ministry discredited new contraceptive methods and prevented their introduction into the country. ${ }^{254}$ In $1990,56.8 \%$ of Soviet women had never used contraceptives and only $21.8 \%$ had used them regularly. ${ }^{255}$ Most Russian women relied on unreliable methods, such as rhythm, withdrawal, and vaginal douches. ${ }^{256}$

Since the Soviet state needed women in the workforce, few women had the time, money or living space to have another child. ${ }^{257}$ An increased desire for smaller families, in part due to growing urbanization, also raised the abortion rate. ${ }^{258}$ Soviet medical professionals have faced incentives that

246. Id.

247. Id. The average cost for an abortion in Russia is $\$ 230$. Id.

248. See Myers, supra note 223.

249. Six out of 10 Pregnancies end in abortion in Russia LifeSite Daily News, at http://www.lifesite.net/ldn/2002/oct/02102206.html (Oct. 22, 2002) (last visited Oct. 13, 2004) [hereinafter Six out of Ten]. This percentage is estimated by Vladimir Kulakov, head of Russia's Scientific Centre for Obstetrics and Gynecology. Id.

250. Myers, supra note 223. Only Romania has more abortions per capita. Six out of Ten, supra note 249.

251. Reuters, Russian Abortion Rate Declines in Russia, Associated Press, July 28, 2003, http://asia.news.yahoo.com/030728/ap/d7sigfvg0.html (on file with author) [hereinafter Rate Declines]. Soviet men did not like to use Soviet-produced condoms because they regarded them as uncomfortable and unreliable. Id.

252. Kotlyar \& Battin, supra note 214 , at 14 . Even Soviet doctors were leery of prescribing oral contraceptives. Rate Declines, supra note 251.

253. Russian Abortion Debate, supra note 8.

254. Kotlyar \& Battin, supra note 214 , at 14.

255. Id. at 13.

256. Id. at 14 .

257. Russian Abortion Debate, supra note 8.

258. Population Matters, Improvements in Contraception are Reducing Historically High 
likewise kept the abortion rate high. ${ }^{259}$ As recently as the late.1980s, obtaining a legal abortion required a subsequent three-day hospital stay; thus, benefiting Soviet hospitals, which are financed by their number of occupied beds. ${ }^{260}$

After the collapse of the Soviet Union ${ }^{261}$ abortions "skyrocketed in the chaos" when jobs and the "social net of communism evaporated overnight."262 In 1988, there were 4.6 million abortions. ${ }^{263}$ In 1992 , there were an estimated 224.6 abortions for every 100 live births. ${ }^{264}$ In 2002 , there were 1.7 million abortions. ${ }^{265}$ Although the abortion rate in Russia has lowered significantly, even today, for every ten births there are about thirteen abortions, compared with approximately three in the United States. ${ }^{266}$

One might assume because of the liberal abortion laws, illegal abortions are rare. However, for every two to seven legal terminations there is one illegal abortion. ${ }^{267}$ Russian women resort to illegal abortions because of the length of hospital waiting lists ${ }^{268}$ and the poor quality of care in state hospitals. ${ }^{269}$ Hospitals have a shortage of anesthetics, a "conveyor belt" approach, and a health service staff that is indifferent and sometimes callous. ${ }^{270}$ "Another deterrent is the patient's inability to keep her hospital visit confidential."271 Because doctors are required to record "abortion" on the certificate of temporary incapacity from work as the reason for a woman's absence from work, co-workers may learn about another co-worker's abortion. ${ }^{272}$

About six million Russian women are infertile, and medical authorities consider abortion to be the "major cause" of that infertility. ${ }^{273}$ About thirteen

Abortion Rates in Russia, Rand Corporation Publication, at http://www.rand.org/publications/ RB/RB5055 (2001) (last visited Oct. 14, 2004).

259. Id.

260. Id.

261. In 1989, the Berlin Wall collapsed and the dissolution of the Soviet Union followed on August 24, 1991. See Six out of Ten, supra note 249; see also LAWs AND PolicIES, supra note 225 , at 153 .

262. Rate Declines, supra note 251 . The first official abortion statistics emerged only in September 1988. Kotlyar \& Battin, supra note 214, at 11.

263. Myers, supra note 223.

264. Kotlyar \& Battin, supra note 214 , at 12 . The official abortion statistics show 3.5 million abortions in 1992. Id. at 11. However, this number is low due to the introduction of "mini-abortions, performed by vacuum aspiration or extraction." Id. at 12 . Both of these methods were not regularly registered as abortions. Id.

265. Myers, supra note 223, at 2.

266. Rate Declines, supra note 251; see also Myers, supra note 223.

267. Kotlyar \& Battin, supra note 214, at 12. "In 1990, there were 172 persons convicted of performing illegal abortions; 91 of them repeated the offense and had caused serious consequences for the patient." Id.

268. Id.

269. Id.

270. Id.

271. Id.

272. Id.

273. Six out of Ten, supra note 249. This figure is out of thirty-eight million females who are of childbearing age. Id. Russian's fertility rate is now the sixth-lowest in the world. LaFraniere, supra note 242. 
percent of Russian married couples are infertile, and in nearly three out of four cases, the infertility is attributed to the woman because of complications from one or more abortions. ${ }^{274}$ The number of infertile women is predicted to increase because at least one out of ten abortions in Russia is performed on a teenage girl. ${ }^{275}$ The average Russian woman has had six to eight abortions in her lifetime, and it was not unheard of to have as many as eighteen. ${ }^{276}$

The rate of post-abortion complications is very high in Russia. ${ }^{277}$ In 1920 , after abortion was legalized, the risk of dying from infection as a result of the abortion was 60 to 120 times higher than the risk of death while giving birth. ${ }^{278}$ In 1988, it was estimated that seventy percent of Russian women suffer from health complications after their abortion. ${ }^{279}$ In Russia, first abortions ${ }^{280}$ have been known to hinder a normal delivery and lead to future problems, including future infertility. ${ }^{281}$ Moreover, abortions are the cause of death for one third of all mothers. ${ }^{282}$

As few as one in four Russian babies are born healthy, and around threequarters of women suffer some sort of illness during their pregnancies. ${ }^{283} \mathrm{~A}$ common problem experienced by pregnant women is anemia, which can increase the chances for premature birth. ${ }^{284}$ Another common problem is preeclampsia or toxemia, which can appear late in the pregnancy and is potentially fatal for both mother and child. ${ }^{285}$ The high rate of abortions affects the ability of women to have healthy, wanted pregnancies. ${ }^{286}$ Furthermore, the complications after the abortions are attributable to infections, disruptions of the menstrual cycle, and disruptions of the ability to conceive. ${ }^{287}$

Russia is also facing a population crisis as young people are moving away. Those who stay are having fewer children, and the life expectancy of men is falling. ${ }^{288}$ Russian health and demographics experts say the trend of

\section{LaFraniere, supra note 242.}

275. Six out of Ten, supra note 249.

276. GENDER POLITICS, supra note 214 , at 311.

277. Interfax Russian News Agency, Russian Abortion Rate One of the Highest - Health Ministry, Nov. 29, 1988 [hereinafter Russian Abortion Rate].

278. Kotlyar \& Battin, supra note 214 , at 16.

279. Russian Abortion Rate, supra note 277.

280. First abortions are abortions in the case of a first pregnancy. See Kotlyar \& Battin, supra note 214 , at 16 .

281. Id.

282. Russian Abortion Rate, supra note 277.

283. Kathleen Knox, Unhealthy Mothers in Russia Get Babies Off to a Poor Start, Radio Free Europe Radio Liberty, at http://www.rferl.org/nca/features/2002/03/220320021 25533.asp (n.d.) (last visited Sept. 27, 2004). Only twenty-eight to thirty percent of newborn babies in Russia fit the definition of healthy, which means suffering from no complications in the birth process. Id.

284. Id.

285. Id.

286. Id.

287. Id.

288. Birth Control, supra, note 218. 
infertility caused by frequent abortions contribute to the low birthrate. ${ }^{289}$ The low birth rate, coupled with the high mortality rate, has fueled the population decline. ${ }^{290}$ "Russia's population, of 145 million, is shrinking by almost 700,000 annually."291

\section{The Abortion Laws Today}

On August 11, 2003, for the first time in nearly half a century, Russia increased its restrictions on abortion. ${ }^{292}$ The Ministry of Health reduced the number of special circumstances that allow for obtaining an abortion between the twelfth week and twenty-second week of pregnancy from thirteen to four: "rape, imprisonment, the death or severe disability of the husband, or a court ruling stripping a woman of her parental rights." 293 The new rules are not intended to force women to "continue with unwanted pregnancies," but rather to encourage use of contraception and traditional family planning measures. ${ }^{294}$

The Russian government cited economic reasons as a factor for imposing the restrictions. ${ }^{295}$ Russia's health ministry has been spending five percent of its annual budget on funding free abortions. ${ }^{296}$ The health ministry's move is also viewed as part of a campaign to reverse the country's demographic decline under pressure from conservative lawmakers and the Orthodox Church. ${ }^{297}$ However, the new restrictions will not greatly affect a woman's access to abortion because more than ninety-three percent of all abortions are performed before the twelfth week. ${ }^{298}$

289. LaFraniere, supra note 242.

290. Blagov, supra note 217. In 2002, the State Statistics Committee's census department announced that Russia's population has fallen by 2.2 million people since a census in 1989. Id. There are roughly 1.6 deaths for every birth. Id.

291. Birth Control, supra, note 218 . The rapidly declining population is a predicament that President Vladimir Putin has called a "creeping catastrophe." Id. United Nations population experts predict that in fifty years Russia will be the world"s seventeenth most populous country, whereas today it is the sixth. LaFraniere, supra note 242.

292. Myers, supra note 223 . This resolution went virtually unnoticed in the country's media. Robert Greenall, Russia turns spotlight on abortion, BBC News Online at http://news.bbc.co.uk/2/hi/europe/3093152.stm (Sept. 16, 2003) (last visited Oct. 14, 2004).

293. Myers, supra note 223.

294. Henry J. Kaiser Family Foundation, Daily Reports, New York Times Examines New Abortion Restrictions in Russia, http://www.kaisernetwork.org/daily_reports/rep_index.cfm? DR_ID=19524 (Aug. 25, 2003) (quoting Anatoly Korsunsky, the health ministry's chief of maternity and childhood health) [hereinafter New Abortion Restrictions].

295. Blagov, supra note 217.

296. Id. According to Lyudmila Pospelova, the head of the ministry's gynecology department, the health ministry had to take measures to limit the number of abortions. $I d$.

297. Id.

298. Kim Murphy, Russia is moving to restrict abortions, Agency eliminates many social conditions that allow procedure after the $12^{\text {th }}$ week, L.A. TIMES, Sept. 21, 2003, http://www.indystar.com/print/articles/6/076491-8446-010.html (on file with author); see also New Abortion Restrictions, supra note 294. 
Today, contraceptives are becoming increasingly obtainable ${ }^{299}$ and more popular. ${ }^{300}$ The free market of capitalism finished off the production of "Soviet-era condoms of thick, dark latex and diaphragms manufactured in only one size," which were replaced by European imports. ${ }^{301}$ Intrauterine devices have been gaining popularity since they were introduced to Russia in $1971 .^{302}$ Even though western oral contraceptives are now available, Russian women have hostile attitudes towards the birth control pill. ${ }^{303}$ Also contributing to the low use of birth control are local gynecologists who offer contraceptive consultations without knowledge of how to use them. ${ }^{304}$

Russia is poor ${ }^{305}$ and economic despair makes having a baby for Russian women a luxury. ${ }^{306}$ Women not only work in Russia's lowest paying jobs but also account for most of the unemployed. ${ }^{307}$ Furthermore, state subsidies to mothers are "miniscule," between 30,000 and 50,000 rubles a month per child, which is roughly $\$ 6$ to $\$ 11^{308}$ Public spending on Russia's overwhelmed, outof-date, and decaying health care system shrank by about one-third in the 1990 s. $^{309}$ Russia ranks 130 th in the world for overall health system performance. ${ }^{310}$

\section{The Possibility of Abortion Laws in the Future}

Abortion is so ingrained in Russian life that Russia is said to have an "abortion culture." 311 According to Dr. Vladimir Serov, the chief gynecologist at the Health Ministry, abortion in Russia has been called a "habit," or a "tradition." 312 Dr. Serov also claims the trend is the result of Russia's "low level of medical culture." 313 It is evident that Russia must break its "habit," but how? Whatever route Russia takes, reducing abortions will take time. ${ }^{314}$ Family planning groups, such as the Open Dialogue on Reproductive Rights,

299. Kotlyar \& Battin, supra note 214 , at 14.

300. See LaFraniere, supra note 242. According to the Rand Corporation, the number of women who use contraceptives has doubled since 1988. Id.

301. Id.

302. Kotlyar \& Battin, supra note 214 , at 14.

303. See id. Birth control pills made their Russia debut in too high a dosage, which scared off some Russian women. LaFraniere, supra note 242.

304. See Kotlyar \& Battin, supra note 214, at 14.

305. Knox, supra note 283.

306. Russian Abortion Debate, supra note 8.

307. Id.

308. Id.

309. Knox, supra note 283.

310. Id. The World Organization estimates that Russia now spends $\$ 251$ per person per year on health care, compared with $\$ 1,700$ per person per year in the European Union. Id.

311. See Russian Abortion Debate, supra note 8.

312. LaFraniere, supra note 242.

313. Id.

314. See id. 
cite some success in lowering the abortion rate through public information campaigns and contraceptives, but changing social attitudes takes time. ${ }^{315}$

Dr. Serov argues that Russia's government must take better care of women's reproductive health by promoting contraceptives instead of abortions. ${ }^{316}$ According to the Health Ministry, the government hopes to set the course with a new program in $2004 .^{317}$ However, with Russia's health care in a state of collapse, it is unknown how this program will be funded. ${ }^{318}$

In the meantime, Russia's parliament is considering proposals for even wider restrictions that would require "psychological counseling and would limit abortions past twelve weeks to cases of rape and unfit parents, including conditions of alcoholism and child abuse." ${ }^{, 19}$ This proposal is much stricter than the abortion laws in the United States. ${ }^{320}$ Aleksandr Chuyev, a member of the lower house of parliament, intends to sponsor a bill that will grant a fetus the same rights as a child. ${ }^{321}$ This bill could possibly turn Russia's abortion laws from some of the most permissive to some of the most restrictive abortion laws in the world. ${ }^{322}$

On the other hand, abortion activists are helping draft a proposed law that would guarantee the right to affordable abortion. ${ }^{323}$ After the government restrictions were implemented, pro-choice campaigners saw the restrictions as "the first step towards an attack on the rights of women." "324

No matter where legislation will be in the future, both sides agree on the need for some form of education for young women. ${ }^{325}$ There is no substantial program for sex education in schools, even though government has discussed having one for ten years. ${ }^{326}$ However, there are worldwide, not-for-profit organizations that are focusing on improving the problem in Russia. The Sexuality Information and Education Council of the United States (SIECUS) ${ }^{327}$ has collaborated with representatives from over twenty Russian organizations to learn more about the current status of sexuality education in Russia and to

315. Id.

316. Id. Dr. Servov also argues that the government should fight the spread of sexually transmitted diseases, which he claims is the second-leading cause of infertility after abortions. Id.

317. LaFraniere, supra note 242.

318. See id.

319. Murphy, supra note 298.

320. Id.

321. New Abortion Restrictions, supra note 294.

322. See id.

323. Russian Abortion Debate, supra note 8.

324. Greenall, supra note 292.

325. Id.

326. Id. Dr. Grebesheva, the director of the Russian Family Planning Association says that "[a] fourteen year old receives no sex education but he can already be convicted for the crime of rape." Id.

327. SIECUS is a national, nonprofit organization that promotes education about sexuality and advocates the right of individuals to make responsible sexual choices. SIECUS, About SIECUS, at http://www.siecus.org/about/abou0000.html (n.d.) (last visited Sept. 27, 2004). 
explore the development of Russian guidelines for sexuality education. ${ }^{328}$ Together, they developed a Framework for Sexuality Education for Russian Youth, which includes information about the life behaviors of a sexually healthy Russian adult, the values needed for a sexuality education program, and the key topics and concepts to address to Russian children and youth. ${ }^{329}$ EngenderHealt ${ }^{330}$ has been working to improve women's health in Russia and to reduce the number of abortions by increasing contraceptive acceptance and use. $^{331}$ EngenderHealth also provides training to local health care facilities through comprehensive post-abortion care services and by improving the quality of family planning and other reproductive health services. ${ }^{332}$

\section{CONCLUSION}

Is Roe $v$. Wade the better solution for Ireland or Russia? To help answer that question, the first step is to look at what would happen in the United States if there was a shift in balance in the Supreme Court which would tip the Court against Roe. ${ }^{333}$ If Roe is overturned, then the United States would be in political turmoil. ${ }^{334}$ But the real focus of overturning Roe should be on the pregnant woman seeking an abortion. ${ }^{335}$ If abortion became illegal again, a pregnant woman would have two choices: she could either have the baby or seek an illegal abortion. Since the number of abortions doubled after $R o e,{ }^{336}$ it is possible that the abortion rate would drop just as much if abortion became illegal. Furthermore, birth control and contraception in the twenty-first century is so advanced, there is no need abortions except for the circumstances of rape, incest, or to save the life of the mother. However, this may be a "rose-colored" view of abortion, because the reality of overturning Roe is that women would simply seek illegal abortions, risking criminal prosecution or even death. ${ }^{337}$

328. SIECUS, Country Specific Guidelines: Russia, at http://www.siecus.org/inter/russia/ index.html (n.d.) (last visited Sept. 27, 2004).

329. Id.

330. EngenderHealth is a nonprofit organization that works internationally to support and strengthen reproductive health services worldwide. EngenderHealth, About EngenderHealth, at http://www.engenderhealth.org/about/index.html (n.d.) (last visited Sept. 27, 2004).

331. Engender Health, Country by Country: Russia, at http://www.engenderhealth.org/ia/ cbc/russia.html (n.d.) (last visited Sept. 27, 2004).

332. Id.

333. See supra note 119 and accompanying text.

334. See supra Part II.C-D.

335. See supra Part II.B.

336. See supra note 70 and accompanying text.

337. This very issue was discussed in the recent U.S. Supreme Court case of Lawrence $v$. Texas. See Lawrence v. Texas, 123 S. Ct. 2472, 2491 (2003). Lawrence involved the constitutionality of a Texas statute that made engaging in homosexual conduct illegal. Id. at 2475. In her concurring opinion, Justice O'Connor stated that overruling Roe would not create a massive disruption of the current social order. Id. at 2491 . Overruling Roe would simply restore the "the regime that existed for centuries before 1973, in which the permissibility of and restrictions upon abortion were determined legislatively State-by-State." Id. The consequence 
The reality is that the United States cannot force acceptance of an unpopular law.

If Ireland adopted Roe $v$. Wade, the number of women who travel to Britain to obtain abortions would certainly decrease. ${ }^{338}$ If the same statistics in the United States after the decision in $R o e^{339}$ hold true in Ireland, the number of abortions will certainly increase. In any event, adopting Roe $v$. Wade may not even be an option because a Catholic-dominated country would not likely allow for the legalization of abortion. ${ }^{340}$

If Russia had adopted Roe $v$. Wade, its abortion rate might still be one of the highest in the world since more than ninety-three percent of all abortions in Russia are performed before the twelfth week. ${ }^{341}$ Therefore, more restrictive case law or legislation would probably not change the rate in Russia without first implementing a program to educate Russian women about reproductive health. ${ }^{342}$

Therefore, although Roe $v$. Wade might be a middle-ground solution between the two extremes, the better answer for the future of Ireland and Russia is to focus on education and advances in the technology of birth control. The answer to the abortion problems. in Ireland and Russia is to educate young women about birth control and the effects abortion may have on them before they become sexually active. The abortion problems of the two countries appear to be so deep that merely establishing new law would not be an appropriate answer.

Regardless, each country can continue to learn from each other for the future of its abortion laws. The United States can learn from Ireland that a woman who is determined to have an abortion will go to great lengths to have that abortion, even if it means breaking the law or even risking her life. ${ }^{343}$ As the current abortion statistics show, the United States can also benefit from educating a young woman about contraception and her own reproductive cycle. $^{344}$

Ireland can learn from the United States that it should work to resolve the ambiguities between Article 40.3 .3 and the judicial decision in the $X$ case. ${ }^{345}$ Ireland's Supreme Court can resolve this by clarifying the uncertainties that its decision created. ${ }^{346}$ However, Ireland's Supreme Court could learn from the

of overruling Roe would not make abortion unlawful; it would only permit the States to make abortion unlawful. Id. Many states would not prohibit abortion. Lawrence, 123 S. Ct. at 2491. Even for persons who live in states that would prohibit abortion, "the choice would not have been between abortion and childbirth, but between abortion and abortion in a neighboring State." Id.

338. See supra notes $176-78$ and accompanying text.

339. See supra note 70 and accompanying text.

340. See HESKETH, supra note 122, at 38-53.

341. See supra note 298.

342. See supra Part IV.D.

343. See supra Part IV.B.

344. See supra Part IV.D.

345. See supra Part III.A; see also notes 150-51.

346. See id. 
U.S. Supreme Court that no matter how clear the decision appears to be, there will always be questions (and therefore future cases) on such a controversial issue. ${ }^{347}$ Even if Ireland has not gained anything from the United States, it still seems Ireland has followed in the footsteps of the United States and has turned abortion into a highly controversial and emotional issue. ${ }^{348}$

The United States can learn from Russia that legalizing abortion with almost no restrictions is not the best solution. ${ }^{349}$ Russia has proven this with the high rate of infertility, post-abortion complications, and the high number of illegal abortions. ${ }^{350}$ This should prove to the United States the importance of teaching its younger generation about sexuality and contraception. ${ }^{351}$

Hopefully Russia will learn not only from the United States, ${ }^{352}$ but also from Ireland, ${ }^{353}$ that extremely restricting abortion regulations is not the best solution. ${ }^{354}$ However, abortion is different in Russia than in the previous two countries because most Russians view abortion as a medical issue rather than a moral issue. ${ }^{355}$ Because abortion laws in Russia have been so liberal for over fifty years, ${ }^{356}$ affecting at least three generations of Russian women, the solution for Russia is patience and education. ${ }^{357}$

Because of the continuing devastating effects on pregnant women obtaining abortions, Ireland and Russia will have to find some middle-ground to their extreme situations; however, a judicial decision such as Roe $v$. Wade might not be the best solution. Although not an instant fix, the best long-term solution for the future of Ireland and Russia is to focus on educating young women about reproductive health.

347. See supra Part II.A, Part II.C.

348. See supra Part III.

349. See supra Part IV.B.

350. See supra Part IV.B.

351. See supra Part IV.D.

352. See supra Part II.

353. See supra Part III.

354. See supra Part II-III.

355. See Kotlyar \& Battin, supra note 214 , at 16.

356. See supra Part IV.A.

357. See supra Part IV.D. 
